\title{
Working the Play: How a Card Game Negotiates Perceptions of Work and Productivity
}

\author{
Andrea Pisac \\ Goldsmiths, University of London, London, UK
}

Based on the ethnographic study of the card game Bela, this paper rethinks the intersections and interstices between game and non-game contexts, challenging the presumption that play is unproductive and non-materialistic. By embedding the rules of the game into its socio-cultural context, the paper identifies a symbolic space of shared stories, emotions and personal interests that coexist with, modify and lubricate the rules of the game. By considering play as a way of engaging the world, rather than a categorically identified, bounded and thus inconsequential activity, I explore how the open-endedness of the card game relates to broader life experiences, and particularly how it shapes and influences perceptions of work and productivity.

Key words:

play, work, productivity, contingency, playfulness as disposition

\section{INTRODUCTION}

Monday nights are boys' cards nights. Once a week, seated at a long dining table in Nino's ${ }^{1}$ house, the four men become boys: free from both family and work duties. The first one to arrive is Teo. He sits opposite Nino and begins chatting about his week: how many times he visited the local gym, how the remodelling of his house is coming along, what parties are coming up. Nino offers a shot of home-made brandy as a welcome. If the remaining

\footnotetext{
${ }^{1}$ Identities of all players have been anonymised.
} 
two players, brothers Marko and Justin, are late, the boys will talk about new mobile phone gadgets, perhaps crouching over Teo's large Samsung screen while he plays a funny video from YouTube. Eventually, Marko and Justin complete the scene, bringing along several bottles of beer. Mađarice, the Hungarian playing cards, a notebook with neatly drawn columns $\mathrm{mi} /$ $v i$ (us/them) and a pen are already waiting on the table. As the glasses are poured and ashtrayes arranged at each corner of the table, Marko recounts his last biking adventure on the Sljeme mountain. "Look at this belly", he puffs reaching for his "spare tyre". "As soon as I start exercising, I gain weight". All but Nino, who is naturally lean, give a long sigh in support to Marko's predicament. "Me too", Justin shakes his head, "I had a good week but then piled everything back on over the weekend". One of the players shuffles the cards and invites the others to cut the deck. Whoever has the highest rank deals. The game starts, stifling the lingering jokes about sport and their masculine efforts for self-improvement.

One Monday night, Teo brought a bottle of whiskey. He arrived early as usual, and took his place at the table as usual. Nino served shot glasses and poured everyone a drink. After the first sip, the boys all commented: "great whiskey, Teo". Cards were shuffled, then cut, then dealt. Justin marked the beginning of a new match in the notebook. I noticed something was different not the same. Short drinks are almost always served by Nino as the host. "Are we celebrating something today", I asked tentatively. Then Teo showed a tiny smile in the corners of his mouth: "My wife is pregnant".

When I had my first conversation with Nino about card-playing, I expressed nostalgia for Bela, a widespread Croatian game. In London, I never found people who knew how to play it. However, during my highschool days, the time of the 1990s war in Croatia, Bela was played almost everywhere - public or private. People turned cafe tables, school and park benches, market stalls and even hospital beds into card playgrounds. I honed my card skills in the bomb shelter of the building where my parents and I lived at the time. Stricken with panic, people squatted around metal collapsible beds and played Bela with neighbours whom they had hardly known before the daily air-raids began. Players were usually teamed up among either women or men of the same age. There were rarely mixed teams, and even when men and women played together, it was always against each other. I played with three teenage girls whom I hardly knew before going to the shelter became our daily routine. After several months of running down the stairs, the panic subsided, yet playing Bela continued - it was a way of killing time, creating a sense of shared experience but also 
of protesting against air-raids controlling our lives. The war was there, but people flocked into groups, shuffling, dealing, and subduing the sounds of the outside world with happy "screams" of winning.

It was obvious that playing Bela meant inhabiting a space and time different from the prevailing extraordinary reality. My memories of playing Bela from those days are of fun and laughter. By the end of 1996 - the year we spent most of our time in the shelter - we grew to enjoy this card game so much that we continued playing in the evenings after school. The pleasure of play is said to derive from doing something which is different and bounded from ordinary life as well as doing something unproductive: for us schoolgirls it was doing something unrelated to school. Similarly, when Nino invited me to observe him and his friends play Bela, he warned me of a possible reluctance from his mates: 'it's a boys' night, we play to get away from work, wives and families".

It took some persuasion to be allowed to attend the boys' Mondays. Mostly through Nino's gentle probing and because we have grown to be close friends, other players decided it was safe for me to "hover" while they played. I, however, was not invisible, and so they soon started explaining to me why and how they play. During one year of observing Bela, what they insisted on most was that they took Monday nights off and to themselves. Mobile phones were switched off, private lives and work put on hold: the centre of attention was the card table and through it, their pride in securing this time-space to "jack in". Because I was "warned" so early on that this was a "boys' business", Teo's announcement of the baby on the way, and the boys' meekness and cheer in receiving it, opened up new questions about Bela-playing: questions about the nature of the intersections and interstices between ordinary life and play, productiveness and pleasure, work and leisure; and of how the boundaries, encounters and slippages between them shape the players' relationships as well as their experience of the world beyond the card table.

\section{WORKS AND PLEASURES OF PLAY}

Through ethnographic descriptions of how the rules of Bela become players' experience of the game, influencing their relationships as well as life outside the game, this paper considers play in three different ways. Each understanding focuses on play as a disposition - a mode of engaging the 
world - rather than a separate activity, opposed to work. Much scholarship on play has conceptualised it as separable from everyday life (timespace bounded, existing in a "magic circle"), safe ("consequence free" or unproductive), and pleasurable or fun (Caillois 2001; Huizinga 1955; Reith 2002). This approach has reinforced the modernist construction of the work/play dichotomy, leaving these features empirically unexamined and assumed to be intrinsic and universal. Ironically, the process of seeking what was remarkable about play and games, has set them apart from other (more "serious") aspects of everyday life. Because of this, studies of play have produced work that falls relatively neatly into a divide between primarily materialist and primarily representationalist approaches. The former approach play as an activity defined by its lack of productivity, inspired by Roger Caillois's assertion that "play is an occasion of pure waste" (Caillois 2001). The latter, of which Clifford Geertz's "Deep Play" (1972) is the best known example, take play to be a grand representation of a culture's (unchanging) socio-economic and symbolic order. In his elegant review of anthropology and play, Malaby (2009) argues that both treatments of play tend to be reductionist inasmuch as they disregard one element of play, which relates to and encapsulates the open-endedness of everyday life: indeterminacy².

Understanding play as a disposition and a mode of engaging with the world does not preclude exploring the (semi-)boundedness of particular games. It, however, refocuses us towards seeing features of play as processual and materially-grounded rather than intrinsic and normative. Thus, in this paper, I explore Bela as a card game with specific rules, outcomes and aims. Although, as will become clear shortly, a game is not reducible to its rules, the way rules are experienced is interesting inasmuch as it reflects a wider social context from which a game has emerged and within which its rules are constantly renegotiated.

Reith (2002) has noted that medieval card games were quite different from the ones emerging around the Age of Enlightenment. In the former, the goal was the acquisition of combinations and melds: a card, thus, had a prescribed value only when grouped with others in a variety of ways. Such a principle arguably reflected the medieval hierarchical society in which the properties of people were predetermined by their position in a

${ }^{2}$ Malaby's understanding of play as a disposition is informed by the works of various authors, such as Bourdieu, de Certeau and Sahlins, who all sought in different ways to overcome determinative pictures of the world. 
social group. The rise of individualism translated into card games through the introduction of the trump card - a card that changes the normal order of cards. First chosen by chance and later through bidding, a trump card correlates with a more mobile society. A card's value was no longer derived from its position, but from its number, suit and rank.

The rules of the game are not only static reflections of social contexts. For example, the boys frequently told me that "it's not enough to know the rules to be a good player". They experienced the playfulness of Bela not only through following the rules, but by interpreting and experiencing them in a way which drew on the knowledge they have of each other outside the game. In other words, shared stories are not only the background for Bela, but largely enrich, modify and lubricate the rules of the game itself. In that sense, understanding Bela as (semi-)separate from ordinary life should not be a categorical starting point, but an opportunity to ask questions as to how and why this boundedness is invoked/evoked.

The second understanding of play concerns the behavioural dynamics between players: who they become and what they perform for each other (and for me as an observer) when playing Bela. For example, over time, Nino has learned the role of a sexed-up heart-breaker, while Teo enjoys playing in a style that the group describes as a "little gay". The roles have partly been chosen by players themselves and partly as a commentary on how they are perceived in "real life": often the very opposite. In addition, playfulness of this kind is usually performed by saying something which would normally be understood as completely the opposite. I once asked them how their playtime has influenced their friendships, to which they replied: "what friendship; we are all here strictly professionally". They suppressed their laughter to keep me in suspense about whether this was a joke or not, and proceeded to elaborate: “Nino is Teo's accountant, Justin worked for Teo, Marko and Justin are brothers so they can't be friends..." This type of playing with meaning relates to Bateson's understanding of play as a mode of meta-communication (Bateson and Bateson 1972), in which meanings conferred from messages routinely meaning one thing, when embedded in an affectual context, can be understood quite differently. As Bateson vividly put: "The playful nip denotes the bite, but it does not denote what would be denoted by the bite" (1972: 181). Such reframing is possible only when the affective nature of social processes is captured, by drawing information from body movements, gestures, facial expression, voice inflection or rhythm. Performing new identities and creating diverse meanings is not an add-on to card-playing, but enters into 
a dynamic relationship with the rules of the game. ${ }^{3}$ So even though they are prescribed to some extent, they are also re-interpreted, extended and made "local" for the players.

The third understanding of play focuses on the ways in which Bela communicates with, relates to and enriches ordinary life. In his essay "Play and Work: A False Dichotomy?", Phillips Stevens (1980) insightfully argues that play as an experiential dimension of engaging the world may be found in any of a number of circumstances, not only in those that are categorically defined as play. In the same vein, Huizinga speaks of the play-element, rather than of play as a separable activity. The play-element can be found in various domains of life and is marked by an interest in uncertainty, the challenge to perform in competition, and behaviour that promotes improvisation and innovation. Moreover, some studies of gambling contexts (typically associated with play), have shown that luck and chance, as elements of indeterminacy, are "worked" at, both technically and emotionally. Sallaz (2009), who himself was a Blackjack dealer in Las Vegas, depicted croupiers as skilful game facilitators, who either overextended or withheld emotional labour from gamblers in order to procure a tip. Similarly, Van Wyk (2013) has argued that money won in the South African Lottery could only be made "safe" if winners "worked" on having good relations with the world of spirits, inhabited by ancestors and others.

Bela-playing captures such ambiguous experiences of play- and workdispositions. Whether this is in a form of card strategies reflecting the boys' understanding of their wider socio-economic dynamics or cardplaying skills being transferred into less game-like contexts, the way the boys worked on their play depicted complex interactions which defied normative categorisations of play and work as each other's opposites. The experience of open-endedness, on this level, could be understood using Green's (2009) concept of tidemarks: any boundary between work and play in this sense is formed through the dynamic of ebb and flow, a line no sooner created than erased by the same social process, its doing, and undoing.

${ }^{3}$ I have written about playfulness as a way of refashioning life experience in situations experienced as a double bind. This work was based upon the challenges that Slovenian croupiers faced in their daily dealings with customers and the casino management (Pisac 2013). 


\section{THE BELA PLAYGROUND}

Bela is played each Monday night at Nino's house. The boys insist that the Bela playground is separate from their ordinary life as well as utterly non-materialistic. "It's just having fun", they say. Instead of taking these assertions at face value, let us explore how this rhetoric is produced and invoked during the game and beyond.

The boys started playing Bela eight years ago, when neither had a serious relationship or was married. Today, all except Nino have wives, and Nino is getting married this year. When asked why they play each week, they fervently claim it is "because they need time and space away from ordinary life”. Yet, Nino's marriage and Teo's baby - ordinary life - have been the central topics discussed and teased about in the breaks between card dealings. The discrepancy between what they say and what they do while playing is performed with various degrees of awareness. So, for example, while they purposefully play with the meaning of their assertion that "they are not friends", they show less reflexivity in how they relate to their ordinary life while playing. Their insistence on "jacking in from real life" is almost always juxtaposed with their wives, "the baby", the marriage, family pets, parents, etc. which, as topics of conversation, fill the symbolic and mental space during card-playing. "Why do you play at Nino's house", I asked them. "So no one can bother us", they all replied. I continued my investigation: "But who would bother you?" The boys broke into a collective giggle, turning their gaze towards Nino. All four started to speak at the same time:

Nino: You always bump into someone and then they want to chat...

[This would happen if they played in their favourite café.]

Marko: Hush, Nino... I can smell a trap in this question. [loud laughs]

[Marko was implying that my question was designed to trip Nino up and make him say that wives would bother them. The boys teased him that he should not say something his future wife might find out.]

Teo: Bloody hell, Nino, keep quiet... [loud laughs]

Marko: All is cool, no one is bothering us... [laughs]

Nino: Am I being naïve? [they all laugh]

The wives "who should have accepted their playtime by now" are always present at the table: if not in body then in spirit. The rhetoric about the boundary between play and ordinary life, therefore, is invoked as a shared 
metaphor of resistance to "the daily grind"; a symbolic performance of their masculinity; and a safe practice of one's assertiveness, even aggression, because after all, this is "just a game".

Let us explore the space of Bela. The table at which the two teams of players sit is a dining table and the linen table-cloth in vivid purple is never removed to mark the beginning of play. Only a deck of cards and a notebook point to an activity which, by the boys' rhetoric, is different from ordinary life. And because "Bela is also about a bit of boozing and having fun in a good company", the table also contains the following: each player has a beer glass, two players share an ashtray at table corners, snack food is served in the centre, and Nino's inquisitive cat walks from one end to another, following the action. The space thus is only marginally used for card-playing. Eating, drinking, smoking, and chatting about topics unrelated to the game become part of the conceptual and reaggregated space of play. This means that "real life", which is geographically discontinuous, becomes conceptually unified and relocated in the embodied experience. The space of Bela, to use Michel de Certeau's term, is not determined by objects and laws found there, but "by the actions of historical subjects which are temporal, ephemeral, full of meaning, emotions and ambiguity" (De Certeau 2011: 117-118).

Bela unfolds through a particular rhythm of play. The boys engage in several rounds of dealing, then stop to chat and tease each other, only to ease back into the game. It has often been suggested (see Reith 2002) that the perception of time common to all gamblers (regardless of whether money is involved) is of a constant repetition of a fleeting present. However long the rate of play, the resolution of the risk is over in an instant; and it is this exhilarating instant that the player lives in. The desire to continually inhabit the present moment annihilates the relationship between cause and effect, thus rendering any past and future outside the game irrelevant to the player. When I inquired the boys about "how long the memory of winning or losing lasts", they all affirmed that "by the next Monday, they never remember the score". However, the rhythm of Bela suggests something different. Ordinary life, which is integrated into play in frequent but random breaks, slips in and disturbs what has been perceived as the players' eternal present. For example, on countless occasions, Nino's cat stopped the play half-way through a hand, inviting laughs more than reprimands. Moreover, the way the rules are negotiated rely on the boys' shared past as well as projected future. If the score becomes irrelevant by the following week's session (eternal present), the boys' continuous play bears on the practice of their friendship (cause-and-effect). 
"They would never play for money", the boys insist, setting themselves apart from "those who play at Bela tournaments". ${ }^{4}$ For them this means "playing properly", ${ }^{5}$ which was defined as: co-operating and never cheating or being aggressive. The ambiguous role of money, especially as studied in gambling contexts (Reith 2002), cannot account alone for diverse motivations for play. It is both vital as a constituent of excitement, but, paradoxically, once in a game, it becomes devoid of economic value. Thus, what is at stake is not the financial value of the wager, but what it represents: player's reputation and the strength of their character, or what Goffman calls "face" (Goffman 2006). However, such symbolic and social values can be produced in both game (money or not) and non-game contexts. For example, as I observed interactions between Bela players beyond Monday nights, I learned that they share the kind of solidarity that involves helping each other with daily tasks and exchanging valuable information, all of which contribute to the informal economy of their respective households. So, contrary to their rhetoric of material disinterest, Bela-playing actually facilitates the exchange of social and symbolic capital between the boys.

\section{FROM RULES TO EXPERIENCE}

\section{a) The Rules}

In the boys' opinions, the rules of Bela, although relatively complex, are easily learned through experience. I have been told that "only knowing the rules makes you a mediocre player", but equally, without knowing them "you can never develop a good strategy and co-operation with your partner". In a sense then, Bela is played by the rules, while at the same time, the rules of Bela are played with. Malaby (2009: 211) has argued that the playfulness disposition is characterised by three elements: acceptance of contingency even in most routinised events (such as rules of the game); readiness to improvise; and becoming an agent within social processes,

\footnotetext{
${ }^{4}$ Bela is increasingly being played at tournaments and for money, a context which inevitably produces other kinds of sociability as well as ideas of play and work. A more thorough examination of these comparisons, however, is beyond the scope of this paper.

${ }^{5}$ Scott (2013) offers a vivid ethnography of Blackjack players at a Cyprus casino and their understanding of "proper play", which concerns not only the rules of the game but also the wider sociability of the table.
} 
although in an importantly restrained way. Engaging Bela in such a way allows the player to move beyond the rules and instead experience the game: the open-endedness of the game thus directly relates with the openendedness of ordinary life.

"What needs to happen in order to win a hand in Bela", I asked the boys. They provided me with a list of ingredients:

1. Luck (good cards for declarations [see below] bringing extra points)

2. Skill (described as a combination of maths and good memory)

3. Strategy within a hand and a set

4. Psychology and co-operation

So how is knowing the rules important in order to start playing with them? Let us inspect the basic composition of the game. Bela is a tricktaking game, in which playing a hand involves eight rounds called tricks (štih). Tricks are evaluated by the value of cards taken. The game is played with a 32-card deck, the total value of which is 162: this is called "a clean hand" (čista igra). A hand is worth more if players announce declarations (zvanje, see figure 1): i.e. if their cards form various sequences (in the same suit), combinations (in the same rank) or a marriage (king and queen). For example, the total value of a hand with a "declaration of 20 " is worth 182 , with a "declaration of 50 " is worth 212 , and so on. To win a hand a team must take as many tricks as to score one point above half a hand's worth (for example 82 in a clean hand).

In each hand one player is the dealer, a function which moves in the direction of play (counter-clockwise). The dealer shuffles the cards, invites a player to their left to cut the deck, and deals two rounds of three cards (giving a total of six) followed by a round of two (talon). After inspecting only the first six cards, each player, in the direction of play, has the opportunity to choose a trump or to pass. The dealer, when it is their turn, must choose. Only then, players can look at the talon.

Declarations are announced before or during the first trick. Regardless of who chooses the trump, the lead player is the one who was dealt the cards first. They can play whichever suit, although if they chose the trump, they normally start with that until all the trumps have been "chased out". Being a lead player significantly changes the strategy of the game, the dynamics between trump and other suits and the rhythm of play. For example, if a lead player's cards are not that strong, they might still risk choosing a trump, expecting that the lead position would "make their cards 
better". After the first card is placed in the middle, other players respond: they must follow suit if they can; break the suit with a trump (presjeći), or, if they have no trump, play any card off-suit. The trick is won with either the highest-ranked card in the suit led or a trump. The winner takes the cards and places them face-down on a pile, after which they "lead" to the next trick.

When all the cards have been played, the value of tricks is counted: highest trump cards, Jack and nine, are worth 20 and 14 respectively while the last trick brings an additional ten points. If the team which chose the trump wins, the points are given to both teams (for example 82 to winners, 80 to opponents); if not, they are said to "have fallen" (pali su) and the total value of the hand goes to the opponent.

\begin{tabular}{|l|l|l|l|l|l|l|l|l|l|l|}
\hline Plain suit rank & & & A & 10 & K & Q & J & 9 & 8 & 7 \\
\hline Value & 20 & 14 & 11 & 10 & 4 & 3 & 2 & 0 & 0 & 0 \\
\hline Trump suit rank & J & 9 & A & 10 & K & Q & & & 8 & 7 \\
\hline
\end{tabular}

Table 1. Cards value

\begin{tabular}{|l|l|l|l|}
\hline Points & Sequence & Combination & Marriage \\
\hline 20 & $\begin{array}{l}\text { of three } \\
\text { (e.g. 7,8,9 or Q,K,A) } \\
\text { if two players have } \\
\text { a 20, the one with } \\
\text { higher-ranked cards } \\
\text { is accepted }\end{array}$ & & $\begin{array}{l}\text { King and queen in } \\
\text { the trump suit (must } \\
\text { be declared when } \\
\text { the first of them is } \\
\text { played) }\end{array}$ \\
\hline 50 & of four & & \\
\hline 100 & of five & four As, 10s, Ks, Qs & \\
\hline 150 & & four 9s & \\
\hline 200 & & four Js & \\
\hline
\end{tabular}

Table 2. Declarations

The way the rules are followed and played with is informed by what might be a player's strategy for a hand, as well as for the whole match. Points won in a hand are added up and the winner of the set is the team who reaches 1001. As Bela is usually played through the evening, the overall winner is a team who wins 3 sets, i.e. a match. 


\section{b) Beyond the Rules}

Through observing and talking about Bela in various contexts, I came to realise that winning was least important. "The combinations of cards of what you, your partner and the opponents might have is actually quite formulaic", Nino told me. It seemed that cards themselves were not as big a challenge to the players as what people could do with them and how they related to each other over them. What was the aim of the game then? I asked each player about his most favourite moment of Bela-playing to uncover the kind of experience which attracted them to play it.

Teo's precious moment was when he was dealt a powerful declaration.

I once got 4 Jacks and 4 Aces. Imagine, 8 strongest cards you can have. I was so happy. I had butterflies in my stomach and I couldn't sleep, that's how excited I felt. [they all laugh because Teo playfully exaggerates the feeling of excitement]

Justin experienced his best moment when he teamed up with Nino, against Marko and Teo, and they broke them on their lead, without giving them a single trick - this is called kontra-štilja (štilja being a hand won with all 8 tricks).

I've played Bela since high-school, and I've played a lot. But before I met Nino, I've never given kontra-štilja to someone. This is a fantastic feeling.

Nino is the only one who remembers a dreadful loss, but what is important is who he lost from.

The worst was when I got beaten by Dalmoši [people from Dalmatia]. Those two usually played for money and had a different style: never pass on choosing a trump. We never stood a chance. You know the feeling? When you can't put a good enough card on the table. I felt so helpless, and to lose from Dalmoši... They don't even play Bela that often.

For Marko, it wasn't the game itself, but what went on around, during and in-between the game.

My fondest memories are of the atmosphere. I still remember all the jokes and pranks that took place each time we met. Of course, the best times happened 
in Teo's mountain house, but we already told you the house doesn't exist. [The non-existent mountain house is a running joke of me not being allowed to know what happened there.] We could show you photos that don't exist [laughs]...

What the boys identified as various aims of Bela relates to Malaby's (2007: 108) four types of contingencies, all of which create a specific experience of the game: stochastic (randomness produced by a well-shuffled deck of cards); social (uncertainty about another's point of view); performative (acting on the guesses about another's point of view); and semantic (unpredictability of what the game's outcomes mean). They are reflected in Bela in the following ways.

\section{THE WHAT: GOOD CARDS FOR DECLARATIONS}

Although the players considered declarations (zvanje) - an outcome of a well-shuffled deck of cards - to be inferior to the skills of strategic playing and co-operation with a partner (znanje), extra points were nonetheless important. The reason why Teo treasures the moment of a great declaration was less about being a passive recipient of luck and more about using it to enhance his self-worth. For example, if the opposing team chose the trump, announcing a strong declaration was used to break their game at a strategically important point.

\section{THE HOW: BREAKING THE OPPONENT WITH KONTRA-ŠTILJA}

Justin's memory was not only of winning, but of how a win was reached, which involved working at it and achieving something rare and exceptional. Hands like kontra-štilja epitomise the most important elements of cooperation with a partner. "This is an ongoing process of learning", I was told, although many tricks and shorthand exchanges "are internalised through a time spent playing". Nino told me to think of each card not in terms of its suit, rank or value but as a communication channel between partners. In other words, reading the cards "properly" was a way of negotiating the social uncertainty about players' intentions. 
Each card is a sign that your partner can interpret in some way. It's not only there to win or lose a trick. For example, if your partner leads with one suit and you win it, you play the same suit back: he's telling you he's done with that suit and wants to "save" a trump for when there's a chance to break the opponents' trick. There are cues that everybody who plays Bela knows, and then there are different styles and peculiarities that only your partner does and knows. It's like a dance, you lead and you follow. A good player knows how to pass the game over to the partner [podigrati partneru].

\section{THE WHO WITH AND WHO AGAINST}

Nino's memory is of a bad loss, however a loss was taken to heart only because it was to particular people who played differently. Among the boys, losing, like winning, had an impact inasmuch as it invoked emotions of closeness, such as teasing and joking. Their bond was less a source of comfort after losing, and more a spring-board for joking and teasing, supporting a sense of play as a meta-communicative act. Nino's "feeling of helplessness" after losing to the "wrong people" invited me to ask how one chooses partners to play with.

Marko: Justin and I are brothers, you can't have two brothers playing together... it doesn't make sense.

Justin: Sure, you can't yell at your brother when he makes a mistake. [laughs]

Teo: You never play Bela with your wife or your brother.

Me: Why not?

Marko: For the same reason a surgeon doesn't operate on their family members.

Me: Do you sometimes play Bela with other people, apart from Monday nights?

Nino: Almost never.

Marko: It's not that we wouldn't want to, but there's no time.

Me: So you would "cheat" on your partner and play somewhere else?

Marko: Who wouldn't want something on the side? [all laugh]

Me: If someone can't make a Monday night, is there a rule who can replace him?

Marko: Teo was gone for two weeks [when the baby was born] and we didn't replace him: so what do you think?

Me: You let me replace Nino once.

Justin: Oh, you're different, you're studying us. 
The co-operation between partner players directly affects how the game is perceived: is it challenging or fun enough? I am told "it's a whole new game when you start playing with 16, and not 8 cards". Nino explained that "a good player" knows how to rely on their partner's cards, while a "supreme player" plays with all 32 cards: i.e. using their memory and odds of various combinations to predict how the whole deck is distributed. I understood that the lead-follow dynamics the boys told me about, just as any rule, depends on the context of the game as well as on players' moods. For example, Nino spoke of how important was to "risk choosing a trump as often as possible", yet, there were many considerations as to how such risk influenced the partners' dynamics:

Taking a risk is always calculated against the overall score. If you're losing and your opponents are almost out, you'd let them choose, hoping you get good enough cards to break them. When the opponent needs only one trick to come out [win the set], you risk it but only if the first six cards in your hand are winners. In this case you don't count so much on your partner's cards: you play safe. In any other case, you always rely on what your partner might have.

The lead-follow dynamic is not rigidly prescribed and requires each partner to sense if it is time to be more aggressive or less. Such strategic dynamics between partners exemplifies Malaby's performative contingency. Acting on the guesses about a partner's point of view can be a source of immense pleasure as well as a source of misunderstandings, leading to what Justin referred to as "losing it and yelling at the partner".6

The boys spoke of such misunderstandings in terms of partners having "different scenarios for the game as a whole". Someone might think they have been dealt strong cards, but as the hand unfolds, their strategy may prove wrong. When team players' perceptions of "the scenario" clash, they can lose a hand even with killer cards. Equally, the value of one's cards either in contributing to a declaration or winning a trick - largely depends on the rhythm of the game: i.e. who leads to a trick (otvara igru). A lead player controls which suits are played first and if trumps are "chased

${ }^{6}$ Studies of Blackjack, which is considered a game of stochastic contingency, have shown that the social dynamics at the table plays a crucial part in the actual outcomes for players as well as their sense of achievement. Marksbury and Scott $(2009 ; 2013)$ vividly depict that even though the rules of Blackjack set players to play individually against the house, it is how they "play together" that becomes critical for the game. 
out" or used to break the opponents' tricks. Therefore both the rhythm of the game (who leads according to rules) and the rhythm between the team players can trump the value and rank of cards. As Marko said: "two exceptional players don't always make a winning team".

\section{THE WHERE AND WHEN: THE ATMOSPHERE}

"The atmosphere is the key", I was often reminded. Marko said "he mostly played for the company of his friends, not because he was a fighter". The context he spoke of reaches beyond the game itself. If an overall strategy for Bela involves "playing with all 32 cards" and "getting in the rhythm with your partner", Marko's idea of the atmosphere evokes dynamics developed and cultivated before card-playing began. The question then is: would cardplaying happen had the boys not been friends before and would they be so committed to it without such previous sentiments? I am told that cardplaying sessions were quite different while the boys were single: "they lasted longer; if you could keep your head up, you played, until the wee hours." Monday was chosen to balance out their socialising on Friday and Saturday nights: "they needed something in the first half of the week not to miss each other". Later on, Mondays remained their cards night to allow for family time on weekends. The boys often said meeting for Bela was their way of resisting busy lives. I understood that, no matter how fun and exhilarating Mondays were, they worked towards them; they made an effort for them to happen. And just as Bela created specific meanings for people who played it in the bomb shelter, its semantic open-endedness provided the boys with a multitude of interpretations as to why they played: from deepening their friendships, relaxing from real-life obligations to creating trust through actually sharing their ordinary life stories.

Having observed countless matches in Nino's house, I learned about the basic rules, strategy beyond the rules as well as individual quirkiness that bent the rules. These idiosyncrasies were rarely questioned or identified as "cheating". The boys perceived them as theatrical performances around which many jokes were spun. However, they made little sense to those who knew nothing about their ordinary lives, as most punch lines derived from a difference between what someone was like "for real" as opposed to during play. For example, Teo always inspected the pile of cards won for the number of trumps. Although this is against the rules, the boys went easy 
on him, while at the same time teasing him for being "an amateur". On the other hand, Nino played a self-assured maverick who keeps a card he will play face down on the table before it is his turn. This way he boasted of knowing the distribution of all cards.

A similar way of performing superiority is to play several tricks, one on top of the other, without removing the cards. Three or four rounds can get piled up like this, with cards so mixed up that only the lead player knows what is what, which is the very message they want to send. This short, vehement show would involve: thumping your hand on the table while placing a card, pulling your body closer to the table and arching over the cards (they're almost all yours), and raising the volume and pitch of your voice to announce victory. Everyone enjoys such dramatic endings. On the one hand, a good combination of cards and a clever strategy makes the hand interesting. And on the other, a performance of these sentiments, which both relate to and contradict the player's "real" character, infuses all four players (regardless of teams) with an experience of fun which is both of here-and-now as well as a conduit between their past and future.

\section{CONCLUSION}

Card games cannot be studied in isolation: they reflect, shape and meet with their social context in diverse ways. If play is understood in normative ways as an activity separated from ordinary life and unburdened with material considerations (as, for example, a kind of emptied out non-work), games are reduced to mere representations of the contexts from which they emerge. Anthropology has produced various studies with the aim of reconceptualising these categorical boundaries. Zimmer (1986) has shown that card-playing among the Gende people influences the village wealth distribution as well as serves as a form of investment by which money is made "alive". As this is achieved by being part of a network of social obligations, it is hardly possible to consider play unproductive or wasteful. Moreover, perceiving fun and excitement as the only emotions driving people to play sets our analysis back to normative definitions and taxonomies, away from the processual nature of play. What other emotions and values can play be productive of? In his study of cardplaying among Jews and Muslims in Casablanca, Levy (2008) comments on the kind of relationships that are made possible through engaging the 
game. For example, those who are considered as not belonging to the same categorical identity in ordinary life may become partners in play. Certain ways of communicating become temporarily appropriate, such as playing with stereotypes that are normally sublimated or treated as dangerous.

Although card-playing creates specific social dynamics, it is also clear that they ripple out to and are ripples of, life outside the game. My ethnography has shown that a boundary between play and ordinary life does exist. However, not as a categorical form but a narrative through which players evoke specific interests and intentions with which they imbue Bela. In this paper, I have engaged with play in diverse ways, perceiving it systematically as a disposition and a mode of engaging the world rather than an activity. This enabled me to rethink each aspect of Bela - a rule-based game, partner's dynamics as well as playful meta-communication - as a mode of behaviour that easily transcends and relates to other non-game contexts. I argued that focusing on the playful disposition (acceptance of contingency, innovation and ability to influence social processes) redirects our focus to the materiality of both game and non-game experiences, opening up new ways of thinking about work as well.

How can we understand the use of skill in Bela-playing: counting, memorising, strategic planning, and, last but not least, emotional labouring between partners? My ethnography suggests that the way the rules of Bela are engaged with relies on a complex dynamic between playing with them and working through them to produce a variety of outcomes. I have argued against any stable division between how play and work are perceived. Not only are they both constituent of the overall experience of Bela but dynamically overlap, merge and seep in and out of the game, creating a sense of belonging that connects players present with their past and future.

Recent studies of play in contexts such as gambling, investment and leisure have argued that play is spreading out into more "serious" sectors of life. Goggin (2012) has described how financial products are positioned as something fun to do, while Cassidy (2013) traces convergences between gambling (serious) and social gaming (playful), asserting that play(ing) involves creative expression and social connections among players. Although relatively immaterial, these outcomes cannot be considered wasteful. In the same vein, the fun of being in good company that Bela players identified as one of the game's aims, involves more than just pleasure: effort is made to continue with Monday nights, technical skill is used to tackle mathematical and combinatory requirements of the game, emotional 
engagement is practiced and extended to synchronise partnerships. Even the understanding of how cards relate to each other (trumps to other suits, for example) as well as how the rhythm of play relates to the value of cards challenges the myth of luck and of the "exceptional" player. Trumps, just like an isolated player, are not enough to win. This understanding of dynamic, negotiable and worked-at matrices of card and human relations spill over the Bela playground: first into what the boys call "the atmosphere" and then into ordinary life.

\section{Acknowledgement:}

The research leading to these results has received funding from the European Research Council under the European Union's Seventh Framework Programme (FP/2007-2013) / ERC Grant Agreement n. 263443.

\section{REFERENCES AND SOURCES}

Bateson, Gregory, and Mary Catherine Bateson. 1972. Steps to an Ecology of Mind. Chicago: University of Chicago Press.

Caillois, Roger 2001. Man, Play, and Games. Urbana: University of Illinois Press.

Cassidy, Rebecca. Forthcoming in October 2013. "Speed Dating: Social Gaming and Real Money Gambling". In Qualitative Research in Gambling: Exploring the Production and Consumption of Risk. Rebecca Cassidy, Andrea Pisac and Claire Loussouarn, eds. London: Routledge.

De Certeau, Michel. 2011. The Practice of Everyday Life. Berkeley: University of California Press.

Geertz, Clifford. 1972. "Deep Play: Notes on the Balinese Cockfight". Daedalus 101/1: 1-37.

Goffman, Erving. 2006. "Where the Action Is". In The Sociology of Risk and Gambling Reader. James F Cosgrave, ed. London and New York: Routledge 225-255.

Goggin, Joyce. 2012. "Regulating (Virtual) Subjects". Journal of Cultural Economy 5/4: 441-456.

Green, Sarah. 2009. "Lines, Traces and Tidemarks: Reflections on Forms of Borderli-ness". EastBordNet, COST Action IS0803 Working Paper. At http://www. Eastbordnet.org.

Huizinga, Johan. 1955. Homo Ludens: a Study of the Play-element in Culture. Boston: The Beacon Press.

Levy, André. 2008. "Playing for Control of Distance: Card Games Between Jews and Muslims on a Casablancan Beach". American Ethnologist 26/3: 632-653.

Malaby, Thomas M. 2007. "Beyond Play A New Approach to Games". Games and Culture 2/2: 95-113. 
Malaby, Thomas M. 2009. "Anthropology and Play: The Contours of Playful Experience”. New Literary History 40/1: 205-218.

Marksbury, Richard A. 2009. "Ethnography in a Casino: Social Dynamics at Blackjack Tables". In Global Gambling: Cultural Perspectives on Gambling Organizations. Sytze Kingma, ed. London: Routledge, 91-113.

Pisac, Andrea. Forthcoming in October 2013. “Croupiers' Sleight of Mind: Playing with Unmanaged 'spaces' in the Casino Industry". In Qualitative Research in Gambling: Exploring the Production and Consumption of Risk. Rebecca Cassidy, Andrea Pisac and Claire Loussouarn, eds. London: Routledge.

Reith, Gerda. 2002. The Age of Chance. London: Routledge.

Sallaz, Jeffrey J. 2009. The Labor of Luck: Casino Capitalism in the United States and South Africa. Berkeley: University of California Press.

Scott, Julie. Forthcoming in October 2013. “Playing Properly' - Casinos, Blackjack, and Cultural Intimacy in Cyprus". In Qualitative Research in Gambling: Exploring the Production and Consumption of Risk. Rebecca Cassidy, Andrea Pisac and Claire Loussouarn, eds. London: Routledge.

Stevens, Phillip Jr. 1980. "Play and Work: a False Dichotomy?" In Play and Culture. Helen B. Schwartzman, ed. Leisure: West Point, NY, 316-323.

Van Wyk, Ilana. Forthcoming in October 2013. "Bad Luck, Slippery Money and the South African Lottery". In Qualitative Research in Gambling: Exploring the Production and Consumption of Risk. Rebecca Cassidy, Andrea Pisac and Claire Loussouarn, eds. London: Routledge.

Zimmer, Laura. 1986. “Card Playing Among the Gende: A System for Keeping Money and Social Relationships Alive”. Oceania 56: 245-263.

\section{Rad na igri: kako kartaška igra oblikuje ideje o radu i produktivnosti}

\section{SAŽETAK}

Članak se bavi granicama između onoga što se smatra ozbiljnim radom i igrom. Počivajući na etnografskoj studiji kartaške igre belota, članak preispituje sjecišta i međuprostore između konteksta igre i ne-igre, dovodeći u pitanje postavku da je igranje neproduktivno i materijalno nemotivirano. Smještajući 'unutrašnjost' igre (strukturu i pravila) u širi društveno-kulturni kontekst, rad otkriva simbolični prostor zajedničkih priča, emocija i osobnih interesa koji supostoje, mijenjaju i potpomažu sama pravila igre. Iako se taj prostor poklapa s konkretnim mjestom i vremenom kartaške igre, on prodire i mnogo dublje u svakodnevni život. Upravo se zbog toga rad, novac i produktivnost dinamički povezuju s onim što se zbiva za kartaškim stolom. Shvaćajući igru kao način odnosa prema svijetu, a ne kao kategorički definiranu aktivnost, članak istražuje kakve društvene odnose i simbolične vrijednosti proizvode i konteksti igre i ne-igre. Postavlja 